\title{
INDICATIONS OF GENTLE FOREST LAND GRABBING IN LATVIA
}

Janis Viesturs ${ }^{1,}$ Mg.oec.; Armands Auzins², Dr.oec., assoc.prof.; Inga Snore ${ }^{3}$ B.sc.soc. 1,2, Institute of Civil Engineering and Real Estate Economics, Riga Technical University

${ }^{3}$ The Latvian Journalist Association

\begin{abstract}
The term land grabbing in scientific literature has been used since approximately 2007 - 2008 to describe a trend of large scale land transactions (deals, acquisitions etc.) in rural areas made mostly by foreign companies or multinational corporations as well as governments. In many places worldwide, such transactions have reached large-scale proportions. There are several similar characteristics that explain what exactly is 'land grabbing', its causes and its consequences. The purpose of this research is to identify the trend of land grabbing in general and then to determine whether land grabbing characteristics are found in Latvia. Specifically, this research is focused on the data analysis of forest land owned by foreigners who own a minimum 500 hectares in at least one region of Latvia.
\end{abstract}

Key words: land grabbing, large-scale land transactions, international real estate transactions, land foreignization.

JEL code: Q15, R3, R15

\section{Introduction}

The term 'land grabbing' started being used worldwide around 2007 - 2008 as food prices increased significantly to describe large scale land deals through either purchase, long-term lease or concessions (www.landmatrix.org) primarily to develop food and biofuels production as well as mining, urbanisation (Zoomers et al., 2017) and other projects in developing nations such as: Africa, Southeast Asia, Latin America and the Caribbean (Borras et al., 2012), post-Soviet Eurasia (Visser and Spoor, 2011), Europe (Petrescu-Mag et al., 2017; Van der Ploeg et al., 2015; Borras et al., 2013) particularly (but not exclusively) in Eastern European countries (Guffens et al., 2012; Cotula and Vermeulen, 2009). The 'land grabbing' nowadays would be more applicable in the broader sense of the term because these dynamics do not only affect land (agricultural lands, forests, rangelands, and coastal lands) but also natural resources in general (FIAN, 2017) for example, 'water grabbing', 'green grabbing'.

The aim of this research is to find out whether large-scale land transactions in rural regions of Latvia can be designated as land grabbing. The research assigns the following tasks: 1 ) to study scientific literature about the history and the characteristics of land grabbing; 2) to identify the major landowners in rural regions of Latvia (specifically, this research is focused on the data analysis of forest land owned by foreigners who own a minimum 500 hectares in at least one region of Latvia); 3) to identify their nationality; 4) to determine whether any of the following land grabbing characteristics can be observed in international land transaction in Latvia: transactions are made on a large scale, violation of the human rights of local people, low land purchase price, low transaction transparency, land ownership concentration, expulsion of native population from the land, buyer is in a dominant position in negotiation and in land transaction, ecological pollution as a result of large size land transactions, changes of the lifestyle of local people.

\section{Methodology}

First, scientific literature was explored to identify the history and the characteristics of land grabbing in the world and in particular in Europe. Then data were collected on about 400 companies in Latvia, each of which owns at least 500 hectares of agricultural or forest land located in one regional territory (all of the entire 500 ha must be located in one region) and in which the owners of the majority or all of the shares are foreigners. Data were obtained from the State Land Service and the Latvian Register of Enterprises. All 400 companies were analysed to determine 
ownership of shares. Then the area of agricultural and forest land owned by foreigners in each of these regions of Latvia was determined. During the period from 15 to 16 January 2018, visits to 8 Latgale municipalities (Karsavas county, Ciblas county, Ludzas county, Zilupes county, Rezeknes county, Dagdas county, Aglonas county, and Kraslavas county) were made and meetings were held with ten local government representatives: seven mayors, two municipality deputies and one qualified specialist, in order to find out the opinion of municipalities regarding the possible international land grabbing occurring in their municipalities (results of questionnaire are revealed in Table 1).

Table 1

\section{Results of questionnaire conducted with 10 representatives of local governments about land grabbing characteristics in these selected regions of Latgale: Karsavas, Ciblas, Ludzas, Zilupes, Rezeknes, Dagdas, Aglonas and Kraslavas visiting Latgale between January 15 and 16, 2018}

\begin{tabular}{|l|l|c|c|c|}
\hline No & \multicolumn{1}{|c|}{ Characteristics of the land grabbing } & Yes & No & Partly \\
\hline $\mathbf{1}$ & Transactions are made on a large scale & 9 & 0 & 1 \\
\hline $\mathbf{2}$ & Violates the human rights of local people & 1 & 9 & 0 \\
\hline $\mathbf{3}$ & Low land purchase price & 8 & 1 & 1 \\
\hline $\mathbf{4}$ & Low transaction transparency & 0 & 8 & 2 \\
\hline $\mathbf{5}$ & Land ownership concentration takes place & 10 & 0 & 0 \\
\hline $\mathbf{6}$ & Expulsion of local people from the land & 0 & 2 & 8 \\
\hline $\mathbf{7}$ & Buyer is in a dominant position in negotiation and in land transaction & 5 & 4 & 1 \\
\hline $\mathbf{8}$ & Environmental pollution & 0 & 10 & 0 \\
\hline $\mathbf{9}$ & Changing the lifestyle of local people & 1 & 9 & 0 \\
\hline
\end{tabular}

Source: author's calculations based on questionnaire

\section{History and the characteristics of land grabbing}

The most significant research institutions for land grabbing today are: Land Matrix project (http://www.landmatrix.org, Bracco et al., 2015; Carroccio et al., 2016); Monitoring of land deals by GRAIN, based on media reports (https://www.grain.org); Reports by the International Institute for Environment and Development (https://www.iied.org, Cotula et al. 2009); The International Food Policy Research Institute (http://www.ifpri.org, Von Braun and Meinzen-Dick, 2009); Oxfam (https://www.oxfam.org); The Oakland Institute (https://www.oaklandinstitute.org, Daniel and Mittal, 2009); European Coordination Via Campesina (http://www.eurovia.org/); European Coordination Via Campesina and The Transnational Institute (https://www.tni.org/, Van der Ploeg et al., 2015); The International Land Coalition (http://www.landcoalition.org); The World Bank (Deininger and Byerlee, 2011).

The primary characteristic that identifies land grabbing deals is the size of area of land controlled by powerful transnational and national economic actors (Friis and Reenberg, 2010), and investment companies and holdings (Bracco et al., 2015). However, there is not only one single characteristic that makes a transaction a land grabbing. For example, land grabbing can also be determined by the amount of capital involved (Hunsberger et al., 2014). Examples of land grabbing include instances when the size of land acquired is relatively vast tracts of land (Borras et al., 2012) or also when the land acquired by foreign entity is disproportionately larger in size in comparison to the average locally owned land holding in the region (FIAN, 2010).

Other determining characteristics that qualify a land transaction as a land grabbing are as follow. 
1) Land grabbing is indeed a global trend that can be observed not only in the Global South, but it also occurs in the North (Van der Ploeg et al., 2015). It is recognized that land grabbing is not a completely new trend. History contains many episodes and countless examples of land grabbing, such as: the seizure of the land of indigenous people in North America, European enclosures in the North, 'agricultural outsourcing' since the 1990s (Vandergeten et al., 2016) or several circles of land grabbing in Central America since the late 19th century (Edelman and Leon, 2013).

2) Low price of resources (Zoomers, 2013; Petrescu-Mag et al., 2017) or acquisition of land below the real estate market values (Carroccio et al., 2016). Foreign investors are not always paying the cheapest price for land resources compared to local speculators, such as arendatori in Bulgaria or native speculators in other Eastern European countries (Borras, 2013). Speculative transactions were also done with agricultural and forest land in Latvia.

3) Occurrence of human rights abuse - influencing the right to food and food security (Franco et al., 2015; Golay and Biglino, 2013; De Schutter, 2009) as well as the right to housing, the right to water, the right to an adequate standard of living, the right to take part in cultural life, the right to work, the right to self-determination and the rights of women (FIAN, 2017).

4) Low transparency in transactions. Strong evidence shows that increased transparency does not prevent land grabbing. Several existing cases show that transparency simply led to more "transparent" land grabs (FIAN, 2013).

5) Land concentration - agricultural as well as forest land concentration is dominant all across the world as well as in Europe (Borras, 2013) and it can be observed together with land grabbing. Both trends are equally significant (Van der Ploeg et al., 2015; Borras, 2012).

6) Expulsion of native people from the land (Borras et al, 2011).

7) Transactions for the most part are not made on equal terms between the investors and local landowners. The bargaining power in negotiating these agreements is on the side of the foreign firm (Von Braun and Meinzen-Dick, 2009).

8) Change in the livelihood of rural communities based on drastic re-ordering of land use (Van der Ploeg et al., 2015).

9) Threat to traditional rural livelihood (White et al., 2012; Zoomers et al., 2017) and environmental sustainability (Vandergeten et al., 2016).

10) Foreignization of land (Borras et al., 2012; Van der Ploeg et al., 2015). Usually land grabbing should be understood as foreignization of the land, but not necessarily always because there is also domestic land grabbing (Borras et al., 2012).

11) Causal relation between land grabbing and events of organized violence (Balestri and Maggioni, 2016).

The main causes of the land grabbing in scientific literature are mentioned:

1) the expected continuation of human growth in the world (Friis and Reenberg, 2010);

2) limited land resources in the world (Friis and Reenberg, 2010);

3) to secure food supplies for land (and water) scarce countries (Edelman et al., 2013; Jagerskog et al, 2012);

4) renewable energy policies in European Union and the subsequent investments from the EU to produce biofuels production (Cotula et al., 2008; Antonelli et al. 2015; Bracco et al., 2015);

5) speculation on future increase in the price of agricultural land (De Schutter, 2009);

6) expectations of higher agricultural commodity prices (Cotula, 2012);

7) the sharp rise in extractive mining, tourism and urbanization (FIAN, 2016). 
Many authors and organizations have a different approach and methodology to determine what land grabbing deals are. This is why the extension, scale, purpose and novelty of land grabbing are estimated differently (Cotula et al., 2014; Garcia, 2017) as well as precise and reliable information in terms of the amount and location of land transactions is very limited and elusive (Friis and Reenberg, 2010). Also, different terms are used to describe a similar process: 'land grab', 'largescale land acquisitions (deals, transactions)', 'land rush', 'rush for farmland', 'large-scale land acquisitions' etc. The most complicated and debated issue in global land grabbing today is how to determine land deals and measure them (Edelman et al., 2013). It must also be taken into account that not all land transactions with land are transparent or publicly available, rather land deals are typically shrouded in secrecy (White et al., 2012).

\section{Foreign-owned agricultural and forest land ownership and gentle land grabbing in Latvia}

According to the "Global map of investments" from LANDMATRIX (www.landmatrix.org), there are no land grabbing transactions in Latvia (data from LANDMATRIX can be used critically for a variety of reasons (Borras, 2016)); and according to the information from GRAIN (www.grain.org), there was only one large transaction with farmland for the size of 1895 ha made in 2015 by the Ingleby Company from Denmark. Is there any ground for asserting that there is no land grabbing in Latvia?

To determine if land grabbing has occurred in Latvia, it must first of all be ascertained whether foreigners have captured a control of extended tracts of land (Borras, 2013) in Latvia. The purpose of this research was to answer the question whether or not land grabbing can be observed in Latvia - by exploring more thoroughly (Borras, 2016) agricultural and forest land acquired during the last 10 to 15 years by foreign-owned companies registered in Latvia as well as by examining other characteristics of land transactions. On January 1, 2017 results reveal that disproportionately large tracts of forest land are controlled by foreign-owned companies in one region of Latvia - Latgale (Table 2). 


\section{The highest percentage of foreign-owned forest and agricultural land in $\mathbf{1 0}$ counties in each of the four main regions of Latvia (Kurzeme, Zemgale, Vidzeme and Latgale)}

\begin{tabular}{|c|c|c|c|c|c|c|c|}
\hline \multicolumn{2}{|r|}{ Latgale } & \multicolumn{2}{|r|}{ Vidzeme } & \multicolumn{2}{|r|}{ Zemgale } & \multicolumn{2}{|r|}{ Kurzeme } \\
\hline County & Forest land, \% & County & Forest land, \% & County & Forest land, \% & County & Forest land, \% \\
\hline Zilupes & 52,39 & Limbažu & 11,29 & Krustpils & 9,71 & Dundagas & 6,02 \\
\hline Ludzas & 40,37 & Alūksnes & 11,21 & Kokneses & 4,51 & Kuldīgas & 5,45 \\
\hline Dagdas & 20,39 & Amatas & 10,81 & Viesītes & 3,26 & Pāvilostas & 5,31 \\
\hline Rugāju & 16,64 & Madonas & 10,71 & Neretas & 3,13 & Talsu & 5,15 \\
\hline Kārsavas & 15,74 & Burtnieku & 9,82 & Plavinu & 3,04 & Skrundas & 4,78 \\
\hline Balvu & 13,96 & Alojas & 9,17 & Jaunjelgavas & 2,64 & Saldus & 3,90 \\
\hline Ciblas & 13,26 & Vecpiebalgas & 9,12 & Auces & 2,35 & Aizputes & 2,84 \\
\hline Aglonas & 12,70 & Mazsalacas & 9,00 & Tukuma & 2,19 & Ventspils & 2,67 \\
\hline Rēzeknes & 12,34 & Ogres & 7,00 & Ozolnieku & 2,15 & Priekules & 0,51 \\
\hline Krāslavas & 11,83 & Smiltenes & 6,96 & Jaunpils & 1,14 & Vainodes & 0,43 \\
\hline \multicolumn{2}{|r|}{ Latgale } & \multicolumn{2}{|r|}{ Vidzeme } & \multicolumn{2}{|r|}{ Zemgale } & \multicolumn{2}{|r|}{ Kurzeme } \\
\hline County & Agricultural land, \% & County & Agricultural land, \% & County & Agricultural land, \% & County & Agricultural land, \% \\
\hline Zilupes & 27,50 & Madonas & 10,59 & Auces & 24,41 & Skrundas & 12,57 \\
\hline Ludzas & 24,54 & Alūksnes & 9,24 & Skrīveru & 20,13 & Dundagas & 9,69 \\
\hline Dagdas & 12,11 & Burtnieku & 7,44 & Tukuma & 11,00 & Aizputes & 9,51 \\
\hline Kārsavas & 12,12 & Amatas & 6,85 & Ozolnieku & 10,74 & Ventspils & 7,50 \\
\hline Rēzeknes & 6,88 & Ērglu & 6,23 & Dobeles & 10,05 & Vainodes & 6,34 \\
\hline Rugāju & 6,83 & Priekulu & 4,63 & Kandavas & 8,39 & Talsu & 6,00 \\
\hline Aglonas & 6,03 & Mazsalacas & 4,30 & Krustpils & 7,67 & Priekules & 5,77 \\
\hline Balvu & 5,75 & Gulbenes & 3,17 & Plavinu & 6,67 & Kuldīgas & 4,25 \\
\hline Ciblas & 5,66 & Alojas & 3,10 & Jaunpils & 5,43 & Durbes & 4,19 \\
\hline Viljānu & 5,26 & Ogres & 3,10 & Viesītes & 3,93 & Saldus & 3,89 \\
\hline
\end{tabular}

Source: authors' construction based on the data from the State Land Service and the Latvian Register of Enterprises

Transactions with agricultural and forest land in rural areas of Latvia are regulated by the Law "On Land Privatization in Rural Areas". On May 1, 2004, a 7-year restriction was imposed after Latvia's inclusion into the European Union, which prevented land transactions by natural and legal persons from the European Union (as well as other countries) in rural areas of Latvia. The restriction was later extended until April 30, 2014. Such restrictions motivated foreigners to get around this limitation by establishing companies in Latvia through which to legally buy property. Since May 1, 2014, legal and natural persons from the European Union Member State or states of the European Economic Area, or the Swiss Confederation have the same opportunity to obtain land according to the same terms as local ones. However, even after the liberalization of the land market in 2014, foreigners continue to use a legal entities for land purchasing. As a result, only $0.5 \%$ of the total area of private land in rural territories of Latvia belongs to foreign natural persons.

Almost ten years ago major foreign companies from Sweden, Norway, Denmark, Germany, Luxembourg, the Netherlands, Cyprus, Austria, Lithuania, Guernsey, Estonia and Belgium (Figure 1) arrived in Latvia with the purpose of acquiring agricultural and forest land. Foreignowned companies currently own approximately $8 \%$ of the total area of agricultural and forest land in Latvia or 340344 ha. 


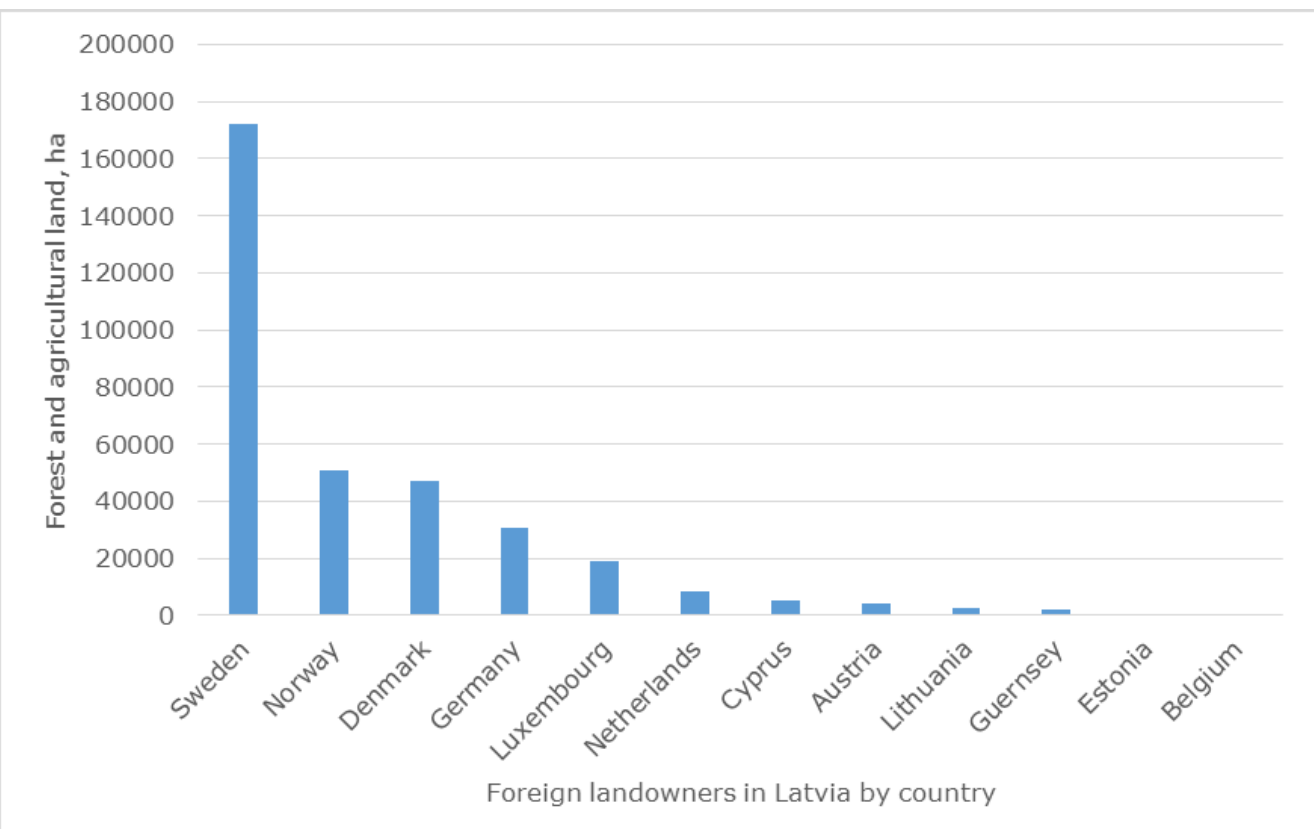

Source: authors' construction based on the data from the State Land Service and the Latvian Register of Enterprises

Fig. 1. Foreign agricultural and forest landowners by country in Latvia on 1 January 2017

It can be concluded that in the part of Latvia - Latgale, foreign forest land ownership is disproportionately large. Therefore, the question whether or not land grabbing exists in Latvia was more thoroughly was researched by analyzing the forest land ownership in the municipalities of Latgale (Figure 2, Table 1). The land concentration in Latgale is evidenced by the fact that the average forest owner owns an area of 10.5 hectares in Latvia (in total 144000 private forest owners in Latvia own 1516164 hectares), but the average area of land owned by one company in 10 municipalities of Latgale is 1237 hectares. Moreover, many of these companies have a related owners.

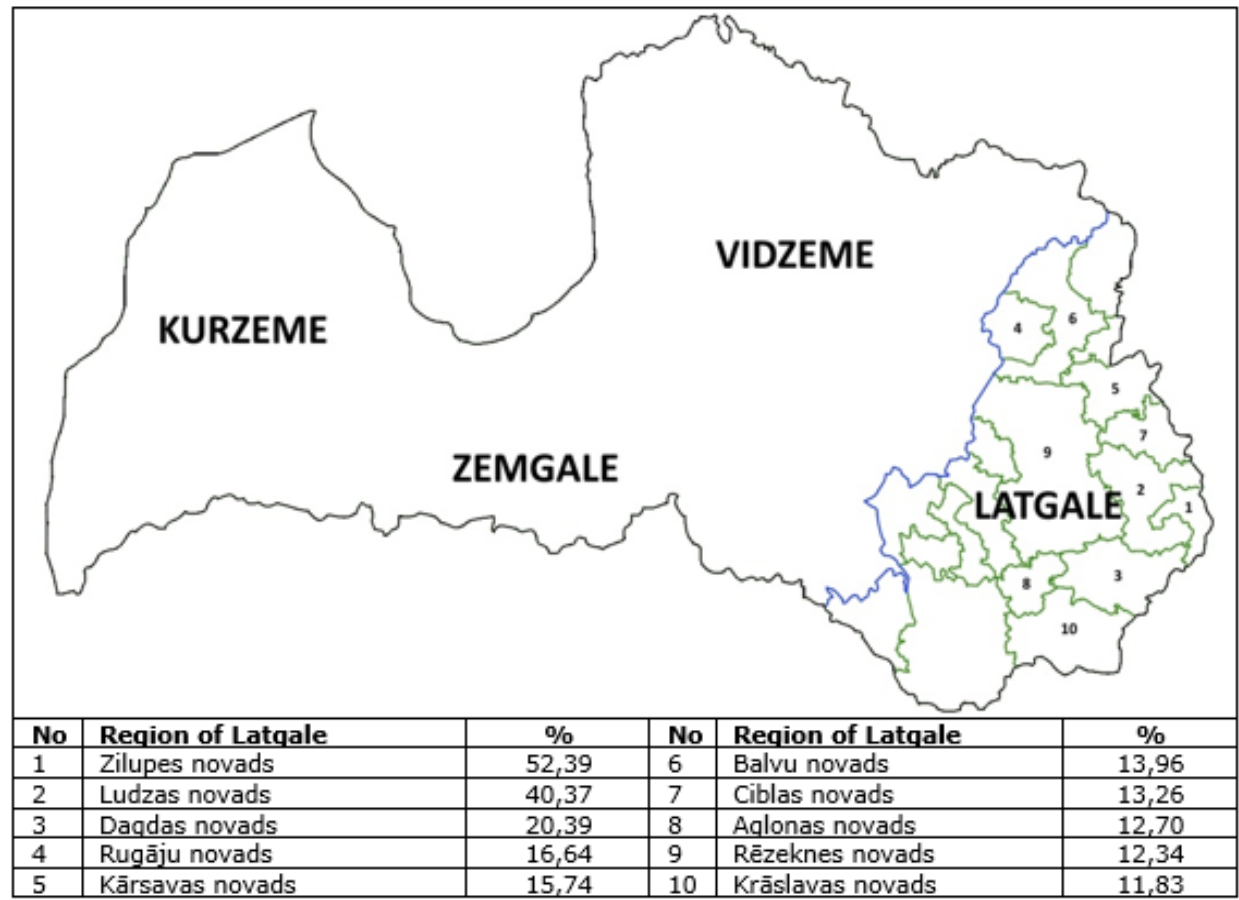

Source: authors' construction based on the data from the State Land Service and the Latvian Register of Enterprises

Fig. 2. Percentage of foreign-owned forest land in 10 regions of Latgale on 1 January 2017 
Representatives of local municipalities in interviews emphasized that foreign-owned land is managed well or even better than among local landowners. Among foreign landowners in Latvia, the largest landowner with more than 100000 hectares is the Swedish company "Bergvik Skog" Ltd. "Bergvik skog" is a nature-friendly forestry company approved by the Forest Stewardship Council (FSC). "Bergvik Skog" Ltd forest management has been certified according to FSC principles (https://ic.fsc.org/en) since 2013. This indicates the good quality of forest management. In general, it can be concluded that the business activities of the foreign forestry companies are characterised by 1 ) high land management culture, 2) afforestation of agricultural and unforested land which have low agricultural value and 3) well organised afforestation of cutovers.

Many authors emphasise native population's displacement as the main consequence of land grabbing. In Latvia, a decrease in the local population can be observed in the regions where highest number of international land deals are carried out. The average amount of population decrease during the period from 1 January 2010 to July 2016 in Latvia was $7.33 \%$, but in regions of Latgale it was significantly higher (Aglonas county $15.29 \%$, Dagdas county $14.31 \%$, Kraslavas county $14.09 \%$, Zilupes county $14.05 \%$, Karsavas county $13.53 \%$, Ciblas county $13.43 \%$, Ludzas county $12.79 \%$, Balvu county $12.79 \%$, Rugaju county $12.66 \%$, Rezeknes county $9.65 \%$ ). However, the reason for decrease in population is a complex mix of socio-political factors, not land grabbing by foreigners. This was also verified by interviews conducted with representatives of local governments (Table 1 ).

Based on this research, it can be concluded that foreign-owned forest land in Latgale can be identified as land grabbing, because transactions as a whole are characterized by their large scale, low price received by landowners, land concentration and foreignization of land. However, the nature of this land grabbing is untypical, because foreign-owned land management is distinguished by good forest management. Therefore, in such cases it would be necessary to introduce this new term "gentle land grabbing".

\section{Conclusions, proposals, recommendations}

1) It can be concluded that there is no uniform land grabbing definition. Its exact definition is determined by the methodology of each study.

2) Upon analysing foreign land ownership in the regions of Latvia, the main land grabbing evidence was found in relation to forest lands in the Latgale, i.e. disproportionately large tracts of forest land are controlled by foreign-owned companies mostly from Sweden. Other characteristics which can be observed in Latgale are land concentration and the low price of resources, but this does not always mean a low price was paid by foreign investors because of speculative activities.

3) In light of the good practice of forest management by foreign landowners in Latvia, it must be acknowledged that in this case land grabbing has a specific nature. It can be said, based on several parameters, that there has been land grabbing, however, this type should be considered as "gentle land grabbing".

4) In order to maintain a healthy proportionality of land ownership between local people and foreigners, the limit of foreigners owned land should be $10 \%$ (let's call it "red line"). This would make it possible to maintain the local population's access to resources. A similar $10 \%$ recommendation has been made in the studies of other authors (Petrescu-Mag et al., 2017) adding that during the market liberalization it is a utopian recommendation and it would be contrary to the principle of the free movement of capital of the EU. It should be the responsibility of foreign 
business entities themselves to choose socially responsible business and do not cross the "red line".

\section{Bibliography}

1. Antonelli, M., Siciliano, G., Turvani M. E., Rulli, M. C. (2015). Global Investments in Agricultural Land and the Role of the EU: Drivers, scope and potential impacts. Land Use Policy, 47, pp. 98-111. https://doi.org/10.1016/j.landusepol.2015.04.007

2. Balestri, S., Maggioni, M.A. (2016). This Land is My Land! Large-Scale Land Acquisitions and Conflict Events in Sub-Saharan Africa. CSCC Working Paper 1/2016, Milan, pp. 1-23. Retrieved: http://hdl.handle.net/10807/97868. Access: 15.10.2017.

3. Borras Jr., S. M., Franco, J. C., Gomez, S., Kay, C., Spoor, M. (2012). Land Grabbing in Latin America and the Caribbean. The Journal of Peasant Studies, 39(3-4), pp. 845-872. https://doi.org/10.1080/03066150.2012.679931

4. Borras Jr., S.M., Franco, J., Van der Ploeg, J. (2013). Land Concentration, Land Grabbing and People's Struggles in Europe: Introduction to the Collection of Studies. Transnational Institute. The Hands off the Land Project, 2013. pp. 6-29. Retrieved: https://www.tni.org/en/publication/land-concentration-landgrabbing-and-peoples-struggles-in-europe-0. Access: 28.12.2017.

5. Bracco Jr., S., Antonelli, M., Turvani, M.E. (2015). Foreign Investment in Land and Corporate Social Responsibility: An Investigation for Africa. African Centre for Technology Studies. Responsible Natural Resource Economy. Nairobi, Kenya: Acts Press, 2015. ISBN 9966-41-171-2

6. Borras Jr., S.M., Seufert, P., Backes, S., Fyfe, D., Herre, R., Michele, L., Mills, E. (2016). Land Grabbing and Human Rights: The involvement of European Corporate and Financial Entities in Land Grabbing Outside the European Union. Directorate-General for External policies. Policy Department. https://doi.org/10.13140/RG.2.2.13719.16800

7. Carroccio, A., Crescimanno, M., Galati, A., Tulone, A. (2016). The Land Grabbing in the International Scenario: the Role of the EU in Land Grabbing. Agricultural and Food Economics (2016) 4:12. https://doi.org/10.1186/s40100-016-0056-7

8. Cotula, L., Dyer, N., Vermeulen, S. (2008). Fuelling Exclusion? The Biofuels Boom and Poor People's Access to Land. IIED, London. ISBN: 978-1-84369-702-2

9. Cotula, L., Vermeulen, S. (2009). 'Land Grabs' in Africa: Can the Deals Work for Development? EEED Briefing. Retrieved: http://pubs.iied.org/17069IIED/. Access: 15.10.2017

10. Cotula, L. (2012). The International Political Economy of the Global Land Rush: A Critical Appraisal of Trends, Scale, Geography and Drivers. The Journal of Peasant Studies, Volume 39, 2012 - Issue 34, pp. 649-680. https://doi.org/10.1080/03066150.2012.674940

11. Cotula, L., Oya, C., Codjoe, E.A., Eid, A., Kakraba-Ampeh, M., Keeley, J., Kidewa, A.L., Makwarimba, M., Seide, W.M., Nasha, W.O., Asare, R.O., Rizzo, M. (2014). Testing Claims about Large Land Deals in Africa: Findings from a Multi-Country Study, The Journal of Development Studies, 50:7, pp. 903-925, https://doi.org/10.1080/00220388.2014.901501

12. De Schutter, O. (2009). Large-scale Land Acquisitions and Leases: A Set of Core Principles and Measures to Address the Human Rights Challenge. Special Rapporteur on the Right to Food. Geneva: UN Office of the High Commissioner for Human Rights, 11 June 2009. Retrieved: https://www.oecd.org/site/swacmali2010/44031283.pdf. Access: 1.10.2017.

13. Deininger, K. and D. Byerlee. 2011. Rising Global Interest in Farmland: Can it Yield Sustainable and Equitable Benefits? The World Bank. Washington, DC USA. 214

p. Retrieved: http://documents.worldbank.org/curated/en/998581468184149953/Rising-global-interest-infarmland-can-it-yield-sustainable-and-equitable-benefits. Access: 5.01 .2018

14. Edelman, M., Leon, A. (2013). Cycles of Land Grabbing in Central America: an Argument for History and a Case Study in the Bajo Aguan, Honduras. Third World Quarterly, Volume 34, 2013, Issue 9, pp. 1697-1722. https://doi.org/10.1080/01436597.2013.843848

15. Edelman, M., Oya, C., Borras Jr., S.M. (2013). Global Land Grabs: Historical Processes, Theoretical and Methodological Implications and Current Trajectories. Third World Quarterly, 34(9), pp. 1517-1531. https://doi.org/10.1080/01436597.2013.850190

16. FIAN (2010). Land Grabbing in Kenya and Mozambique: A Report on Two Research Missions - and a Human Rights Analysis of Land Grabbing. Heidelberg: FIAN International, 2010, p. 8.

17. FIAN (2013). International Statement. G8 Should Implement the CFS Tenure Guidelines Rather than Launch a New Initiative Aimed at Increased Transparency in Land Transactions. 15 May 2013. Retrieved: http://www.fian.org/fileadmin/media/publications_2015/Statement_G8_Land_Transparency_Initi ative_Final_EN.pdf. Access: 12.10.2017.

18. FIAN (2017). Land Grabbing and Human Rights: The Role of EU Actors Abroad. Prepared by Elyse Mills. Heidelberg: FIAN International, 2017, pp. 1-39.

19. Franco, J.C., Monsalve, S., Borras, Jr., S.M. (2015). Democratic Land Control and Human Rights. Current Opinion in Environmental Sustainability 2015, 15, pp. 66-71. http://doi.org.10.1016/j.cosust.2015.08.010

20. Friis, C., Reenberg, A. (2010). Land Grab in Africa: Emerging Land System Drivers in a Teleconnected World. GLP Report No. 1. GLP-IPO, Copenhagen.

Retrieved: http://www.ihdp.unu.edu/docs/Publications/GLP/GLP_report_01.pdf. Access: 15.12.2017 
21. Golay, C., Biglino, I. (2013). Human Rights Responses to Land Grabbing: a Right to Food Perspective. Third World Quarterly, Volume 34, Issue 9, pp. 1630-1650. https://doi.org/10.1080/01436597.2013.843853

22. Guffens, C., Kroff, F., Seufert, p. (2012). Transnational Institute.

Retrieved: https://www.tni.org/files/download/15._tenure_guidelines.pdf. Access: 12.10.2017

23. Hunsberger, C.A., Borras, C.A. Jr., Franco, J.C., Chunyu, W. (2014). Large-Scale Land Transactions: Actors, Agency, Interactions. From "Rethinking Global Land Use in an Urban Era," edited by Karen C. Seto and Anette Reenberg. 2014. Strungmann Forum Reports, vol. 14, pp. 201-215. http://dx.doi.org/10.7551/mitpress/9780262026901.003.0011

24.Jagerskog, A., Casco, A., Harsmar, M., Kim, K. (2012). Land Acquisitions: How will they Impact Transboundary Waters? Report Nr 30. SIWI, Stockholm. Retrieved: http://www.siwi.org/publications/landacquisitions-how-will-they-impact-transboundary-waters/. Access: 12.10.2017

25. Lambin, E.F., Geist, H.J., Lepers, E. (2003). Dynamics of Land-use and Land-cover Change in Tropical Regions. Annual Review of Environment and Resources, 28, pp. 205-241. https://doi:10.1146/annurev.energy.28.050302.105459

26. Petrescu-Mag, R.M., Petrescu, D.C., Petrescu-Mag, I.V. (2017). Whereto Land Fragmentation-Land Grabbing in Romania? The Place of Negotiation in Reaching Win-win Community-based Solutions. Land Use policy. 64 (2017), pp. 174-185. https://doi.org/10.1016/j.landusepol.2017.01.049

27. The 10 FSC Principles. Retrieved: https://ic.fsc.org/en/what-is-fsc-certification/principles-criteria/fscs-10principles

28. Van der Ploeg, J.D., Franco, J.C., Borras Jr. S.M. (2015). Land Concentration and Land Grabbing in Europe: A Preliminary Analysis. Canadian Journal of Development Studies, 36:2, pp. 147-162. http://dx.doi.org/10.1080/02255189.2015.1027673

29. Vandergeten, E., Azadi, H., Teklemariam, D., Nyssen, J., Witlox, F., Vanhaute, E. (2016). Agricultural Outsourcing or Land Grabbing: a Meta-analysis. Landscape Ecology, March 2016. http://doi.org/10.1007/s10980-016-0365-y

30. Visser, O., Spoor, M. (2011). Land Grabbing in Post-Soviet Eurasia: the World's Largest Agricultural Land Reserves at Stake, Journal of Peasant Studies, 38:2, pp. 299-323. http://dx.doi.org/10.1080/03066150.2011.559010

31. Von Braun, J., Meinzen-Dick, R. (2009). "Land Grabbing" by Foreign Investors in Developing Countries: Risks and Opportunities. IFPRI Policy, Brief 13.

Retrieved: http://www.landcoalition.org/sites/default/files/documents/resources/ifpri_land_grabbing_apr_0 9-2.pdf. Access: 25.09.2017

32. White, B., Borras Jr., S.M., Hall, R., Scoones, I., Wolford, W. (2012). The New Enclosures: Critical Perspectives on Corporate Land Deals. The Journal of Peasant Studies, Vol. 39, pp. 619-647. http://dx.doi.org/10.1080/03066150.2012.691879

33. Zoomers, A. (2013). A Critical Review of the Policy Debate on Large-Scale Land Acquisitions: Fighting the Symptoms or Killing the Heart? African Studies, Volume 29, pp. 55-77. http://doi.org/10.1163/9789004252646_004

34.Zoomers, A., Noorloos, F., Otsuki, K., Steel, G., Van Westen, G. (2017). The Rush for Land in an Urbanizing World: From Land Grabbing Toward Developing Safe, Resilient, and Sustainable Cities and Landscapes. World Development, Vol. 92, pp. 242-252. http://dx.doi.org/10.1016/j.worlddev.2016.11.016 